\title{
CHEATING IN ONLINE LEARNING PROGRAMS: LEARNERS' PERCEPTIONS AND SOLUTIONS
}

\author{
Dr. Mohammadreza VALIZADEH \\ ORCID: 0000-0002-4312-9731 \\ Faculty of Humanities \\ Cappadocia University \\ Nevsehir, TURKEY
}

Received: 08/01/2021 Accepted: 23/06/2021

\begin{abstract}
This study aimed at highlighting the Turkish higher education learners' perceptions of cheating on online learning programs, the ways of, causes for, and some suggestions to minimize cheating. Both quantitative and qualitative data were gathered from 163 online learners via a questionnaire including both open-ended and close-ended questions. Data from the close-ended items in the questionnaire were analyzed in terms of frequencies and percentages of the responses using SPSS 22. The open-ended questions were analyzed thematically and manually. Over half of the respondents believed that cheating is more frequent and easier in an online course and they take this opportunity. They cheated by 'using online sources like Google to copy and paste the answers', 'consulting with others, and 'using personal class notes or coursebook'. They cheated because of 'lack of knowledge', 'getting higher marks', 'some technical problems', 'no proctoring', and 'exam stress'. To prevent cheating the respondents suggested that universities should disable the copy and paste features. Teachers should create different quizzes for each student, require all students to start their webcam during the online test, use alternative methods of assessment, prepare essay like thought-provoking questions, and create awareness of the problem. However, some students clearly stated that nothing can be done either due to some technical infrastructure problems or even lazy teachers.
\end{abstract}

Keywords: Cheating, learner perceptions, online distance learning, virtual/online classes, online exams.

\section{INTRODUCTION}

Online learning, as a form of distance education, is any learning experience or environment which depends on the Internet as the main delivery mode of communication and presentation (Appana, 2008). Via online instruction, learners can get an educational opportunity without physically attending the classes and several universities all around the world have delivered online education to encourage and improve learning (Kamal \& Radhakrishnan, 2019). Several studies have already indicated various benefits for online learning. For example, online education enables adult learners who have full-time jobs or family responsibilities to attend classes without having to leave their jobs (Park \& Choi, 2009; Tekinarslan, 2008). Moreover, online instruction has been utilized worldwide by many educational institutions due to the requirement of social distancing under the Covid-19 pandemic to both protect the learners' health and not interrupt their academic studies (Gunes, 2020; Hodges, Moore, Lockee, Trust, \& Bond, 2020). Nevertheless, online instruction can include several problems, such as lack of live interactions with peers and their teachers (Dumford \& Miller, 2018; Kim, Liu, \& Bonk, 2005), lack of opportunity to obtain feedback or receive answers to their questions in real time (Kim et al., 2005), the shorter time of virtual classes, and more opportunities to cheat (Corrigangibbs, Gupta, Northcutt, Cutrell, \& Thies, 2015; Nguyen, Keuseman, \& Humston, 2020; Raines et al., 2011; Saleh \& Meccawy, 2021; Watson \& Sottile, 2010).

"Cheating occurs when a student obtains or attempts to obtain some advantage or extra marks by any dishonest or deceptive means" (Diego, 2017, p. 123). Some researchers argued that formative or summative assessments which are used to measure learning in online courses do not truly reflect learning because it is possible that they are achieved by cheating which occurs during these online assessments (I. J. M. Arnold, 2016; Harmon, Lambrinos, \& Buffolino, 2010). The problem of academic dishonesty in online classes in the 
form of cheating continues to grow (Golden \& Kohlbeck, 2020) and understanding the learners' attitudes towards cheating in online learning is significant to the instructors and administrators.

In Turkey, some universities have adopted well-planned online learning for more than a decade (Kaya, 2012). Further, the COVID-19 pandemic compelled Turkish universities to teach learners online so as not to interrupt their academic studies (Erkut, 2020; Gunes, 2020).

The issue of cheating in online instruction and assessment is central to consider while running the online courses and exams in Turkey like any other country because, in the absence of a proctor and confirmation of the learner's identification, the question of who is taking the test or completing an assignment is problematic to faculty and administrators (Raines et al., 2011; Watson \& Sottile, 2010).

\section{LITERATURE REVIEW}

Literature includes some works which determined several ways learners already used to cheat in online courses. For example, learners were more likely to obtain answers from others during an online test (Saleh \& Meccawy, 2021; Watson \& Sottile, 2010). Other found ways of online cheating include students' dishonest collaboration and sharing assignments with one another (Hearn Moore, Head, \& Griffin, 2017; McGee, 2013; Sendag, Duran, \& Fraser, 2012) as well as copying the information from the Internet or other learners' answers (Diego, 2017; Golden \& Kohlbeck, 2020; Hosny \& Fatima, 2014; Saleh \& Meccawy, 2021).

Hearn Moore et al (2017) also identified several problems in conducting an online course and in administering an online exam. The following are what they found:

(1) identifying the test taker, (2) preventing the theft of the exam, (3) combating the unauthorized use of textbooks andlor notes, (4) preparing an online exam and exam setup, (5) realizing a student may have access to a test bank, (6) preventing the use of cell phones, hand-held calculators, andlor Bluetooth devices, (7) limiting access to other individuals during the exam time, (8) ensuring a student is using a computer with adequate uploading and downloading capabilities, (9) identifying intentional computer crashes, and (10) noting the different methods of proctoring exams. (p. 9)

Additionally, the literature indicates some reasons that cause learners' online cheating. For instance, lack of responsibility, laziness, lack of respect for academic rules, and showing no interest or being unwilling to study as well as low self-esteem are the most important internal reasons (Diego, 2017). In addition, peer influence (Diego, 2017), getting passing grades, not necessarily knowledge (Saleh \& Meccawy, 2021), getting passing grades to please their parents (Diego, 2017; Finchilescu \& Cooper, 2018; Hosny \& Fatima, 2014; Jian, H., Li \& Wang, 2020), the exam difficulty, not being able to prepare for the exam (Diego, 2017; Hosny \& Fatima, 2014), non-existence of punishment or consequences when being caught cheating (Diego, 2017; Hosny \& Fatima, 2014; Jones, 2011; Peled, Eshet, Barczyk, \& Grinautski, 2019; Yang, Huang, \& Chen, 2013), being absent from lessons (Hosny \& Fatima, 2014; Saleh \& Meccawy, 2021), lack of study time, willingness to help friends (Hosny \& Fatima, 2014), and technical problems occurring during an online exam (Saleh \& Meccawy, 2021) are among the external causes.

Diego (2017) reported the reasons that students had for their cheating. The participants were 16 students randomly selected among Junior and Senior High School learners of Roxas National Comprehensive High School in Palawan. Diego found that "the behavior about cheating during exams is deeply rooted in the culture of 'social acceptance/liking' and 'debt of gratitude'. If a student does not share his or her answers, he or she will be labeled as 'no concern'” (p. 122). Diego also argued that:

honesty should not be just a policy; rather, honesty in this case, is the only policy. Condemning academic dishonesty must not merely rest in the enrollment forms but by constant moral reminder and intervention of teachers who have a responsibility to hone learners' decorum on honesty and maturity. (p. 122) 
Solving the problem of cheating in online education is essential to alleviate this concern and implement the online programs effectively (Saleh \& Meccawy, 2021). Furthermore, academic dishonesty is not a new concept, yet online examinations require different strategies in comparison to the traditional tactics (Michael \& Williams, 2013). As a result, some studies already investigated this issue. The most important point which faculty, students, and administrators must consider is creating awareness of the problem of not respecting academic integrity (Michael \& Williams, 2013; Razek, 2014; Tatum \& Schwartz, 2017). In addition, giving paraphrased questions instead of verbatim test questions can decrease the chance of cheating (Golden \& Kohlbeck, 2020). Moreover, online proctoring is an effective tool to minimize academic dishonesty in online exams (Dendir \& Maxwell, 2020; Golden \& Kohlbeck, 2020; Michael \& Williams, 2013).

Most recently, Saleh and Meccawy (2021) explored 57 English language female graduates' perceptions of cheating on a distance learning program at King Abdulaziz University (KAU), their ways of cheating, causes for cheating, and some solutions to minimize cheating. The researchers found that the majority of female students cheated by helping each other, obtaining the correct answers from or sending the correct answers to the other students, and using websites to copy and paste the answers into their tests. The reasons for cheating in distance learning programs were technical problems, the frequent absence of virtual classes, and students wanting grades, not necessarily knowledge. Raising students' awareness of cheating policy and solving the usual technological issues were recommended to minimize the occurrence of cheating.

\section{The Present Study}

Whereas efforts are devoted to addressthe cheating concern based on what teachers know, it is also necessary to explore how learners do it based on their own narratives (Harmon et al., 2010; King, Guyette, \& Piotrowski, 2009; Watson \& Sottile, 2010). To the best knowledge of the researcher of the present study, no research has been published on cheating in online learning programs at universities in Turkey. Therefore, this study tried to identify the perceptions of the Turkish higher education learners who received online learning in terms of how they cheat and why they cheat in online classes; in addition, the study attempted to offer some possible solutions to this problem. Consequently, this research addressed the following questions:

1. In what ways do Turkish higher education online learners cheat?

2. What are Turkish higher education online learners' reasons for cheating?

3. What practical solutions are proposed by Turkish higher education online learners to prevent cheating in online learning?

\section{METHOD}

\section{Design}

This study employed both quantitative and qualitative approaches in types of questions, research methods, data collection, and analysis procedures; therefore, considering the definition of mixed methods, provided by Tashakkori and Teddlie (2003), this study has a mixed-methods design. In terms of the sampling strategy, purposeful sampling was utilized to select cases from whom a lot of insights and in-depth understanding about issues of considerable importance to the purpose of the inquiry can be yielded (Patton, 2014).

\section{Participants}

The participants were 163 Turkish higher education learners who had experienced both traditional real faceto-face learning and online education. Table 1 provides a summary of participants' background characteristics. 
Table 1. Participants' background characteristics

\begin{tabular}{cccc}
\hline & & Frequency & Percentage \\
\hline \multirow{2}{*}{ Gender } & Female & 94 & 57.7 \\
& Male & 69 & 42.3 \\
\hline \multirow{3}{*}{ Educational Level } & Prep (Preparatory) University & 71 & 43.6 \\
& Undergraduate & 78 & 47.9 \\
\hline \multirow{2}{*}{ Age } & Postgraduate & & \\
& Mean & 25.91 & \\
\end{tabular}

\section{Instruments}

Data were gathered using a questionnaire, which was designed to collect both qualitative and quantitative data. The questionnaire incorporated the adapted items which had already been developed by King et al., (2009) as well as Saleh and Meccawy (2021). The author of the present study carefully thought about the original items in the questionnaire to improve them in terms of wording and clarity. Moreover, to pursue the whole aims of the research, two open-ended questions were added to the original questionnaire. Therefore, quantitative data were obtained via close-ended questions with the response in Likert-scale format. Qualitative data were acquired through open-ended questions.

The questionnaire included three sections. The 1st section provided biodata about the participants' gender, age, and educational level. The 2nd section incorporated three items on the Likert scale inquiring about Turkish higher education learners' perceptions about cheating in online learning. The 3rd section included ten questions about the learners' perceptions of methods of cheating. The 4th part contained six open-ended items and one close-ended question seeking the learners' perceptions about reasons for cheating. The 5th section had five open-ended items and one close-ended question asking the learners' solutions to minimize cheating. For part 2, the participants needed to read the statements and select one of the options of 'Strongly Disagree', 'Disagree', 'Not Sure', 'Agree', and 'Strongly Agree'. For part 3, the learners selected one of the options of 'Always', 'Often', 'Sometimes', 'Rarely', and 'Never'. For parts 4 and 5, the participants needed to read the statements and select one of the options of 'Strongly Disagree', 'Disagree', 'Agree', and 'Strongly Agree'.

\section{Data Collection Procedure}

Before the study was carried out, the questionnaire was piloted with a similar group of 10 learners. The reliability of the questionnaire, estimated via Cronbach Alpha, was .718, indicating an acceptable level of internal consistency (Pallant, 2013).

The questionnaire was distributed to 211 learners of online learning, studying at different universities in Turkey. Their participation was voluntary and solicited via online Google Form. Learners were informed that by completing and returning the questionnaire, they had consented to participate in the study. Learners responded to the questionnaire anonymously. Out of 211 learners, 163 students completed and submitted the questionnaire.

\section{Data Analysis}

Data from the close-ended items in the questionnaire were analyzed in terms of frequencies and percentages of the responses, using SPSS 22. The open-ended questions were analyzed thematically, using the guidelines explained by Braun and Clarke (2006). First, the written data from the answers to the open-eneded questions were copied and pasted on a separate sheet of paper under each relevant question. As the participants were allowed to write their answers in their native language (Turkish in this context), the answers written in the Turkish language were translated into English. Then, the researcher read and reread the data, generated and noted down initial ideas (codes) using an inductive approach, whereby the identified themes were strongly 
linked to the data themselves (Reichertz, 2014). Then, the initial codes were collated into possible themes and all data relevant to each theme were gathered. The themes were reviewed to check whether they work in relation to the coded extracts and the entire data set. Finally, the specifics of each theme were refined and clear definitions and names for each theme were generated.

To enhance the dependability of this qualitative research, an outside researcher who holds a $\mathrm{PhD}$ in Applied Linguistics and was experienced in doing qualitative data analysis was asked to review the careful documentation done by the researcher in the present study to explore their accuracy and the extent to which the conclusions were grounded in the data (Nassaji, 2020).

To obey the principle of credibility in qualitative research, which concerns the truthfulness of the findings, the researcher employed the strategy of member checking by sharing the data and interpretations with 20 participants in the research to see if they agree; via this strategy, the researcher ensured that his understanding of the research participants' perceptions and suggested solutions are as accurate and complete as possible (Nassaji, 2020).

\section{RESULTS AND DISCUSSION}

\section{Learners' Perceptions about Cheating in Online Learning}

Table 2. Turkish Higher Education Learners' Perceptions about Cheating in Online Learning

\begin{tabular}{|c|c|c|c|c|c|c|c|c|c|c|}
\hline & \multicolumn{2}{|c|}{$\begin{array}{l}\text { Strongly } \\
\text { Disagree }\end{array}$} & \multicolumn{2}{|c|}{ Disagree } & \multicolumn{2}{|c|}{ Not Sure } & \multicolumn{2}{|c|}{ Agree } & \multicolumn{2}{|c|}{$\begin{array}{c}\text { Strongly } \\
\text { Agree }\end{array}$} \\
\hline & 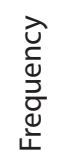 & 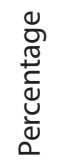 & 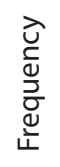 & 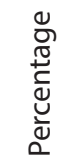 & 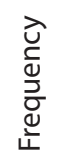 & 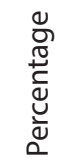 & 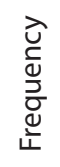 & 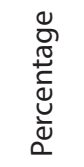 & 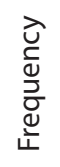 & 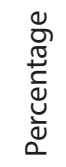 \\
\hline $\begin{array}{l}\text { Students may take the } \\
\text { opportunity to "cheat" in } \\
\text { an online course. }\end{array}$ & 10 & 6.1 & 19 & 11.7 & 40 & 24.5 & 73 & 44.8 & 21 & 12.9 \\
\hline $\begin{array}{l}\text { Cheating is more } \\
\text { frequent in an online } \\
\text { course than in a } \\
\text { regular traditional real } \\
\text { classroom. }\end{array}$ & 6 & 3.7 & 19 & 11.7 & 41 & 25.2 & 70 & 42.9 & 27 & 16.6 \\
\hline $\begin{array}{l}\text { It is "easier" for a } \\
\text { student to cheat in an } \\
\text { online course than in } \\
\text { a traditional classroom } \\
\text { course. }\end{array}$ & 7 & 4.3 & 18 & 11.0 & 29 & 17.8 & 76 & 46.6 & 33 & 20.2 \\
\hline
\end{tabular}

As Table 2 shows, more than half of the respondents (57.7\%) stated that students may take the opportunity to cheat in an online course, and very few students $(17.8 \%)$ did not believe so. Likewise, more than half of the participants $(59.5 \%)$ believed that cheating is more frequent in an online course than in a regular traditional real classroom, and very few students $(15.4 \%)$ did not agree on this point. Similarly, more than two-thirds of the students $(66.8 \%)$ said that it is easier for a student to cheat in an online course than in a traditional classroom course, and very few learners (15.3\%) disagree on this item. Similar findings were revealed in several previous studies (Best \& Shelley, 2018; Miller \& Young-Jones, 2012; Saleh \& Meccawy, 2021; Srikanth \& Asmatulu, 2014; Watson \& Sottile, 2010). These findings of the current study are not similar to what Black, Greaser, and Dawson (2019) as well as Peled et al., (2019) indicated. They indicated that learners were less likely to cheat in online courses than face-to-face ones. 


\section{Methods of Cheating in Online Exams}

Table 3. Turkish Higher Education Learners' Perceptions on Methods of Cheating

\begin{tabular}{|c|c|c|c|c|c|c|c|c|c|c|}
\hline & \multicolumn{2}{|c|}{ Always } & \multicolumn{2}{|c|}{ Often } & \multicolumn{2}{|c|}{ Sometimes } & \multicolumn{2}{|c|}{ Rarely } & \multicolumn{2}{|c|}{ Never } \\
\hline & 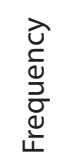 & 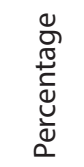 & $\begin{array}{l}\text { ปे } \\
\frac{c}{d} \\
\frac{\partial}{0} \\
\frac{d}{4}\end{array}$ & 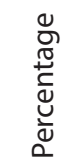 & 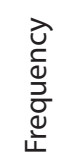 & 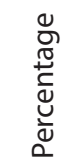 & 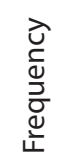 & 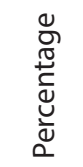 & 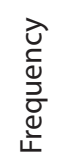 & 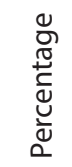 \\
\hline $\begin{array}{l}\text { Did/Do you as an } \\
\text { online student open } \\
\text { the coursebook during } \\
\text { an online exam? }\end{array}$ & 13 & 8.0 & 45 & 27.6 & 62 & 38.0 & 37 & 22.7 & 6 & 3.7 \\
\hline $\begin{array}{l}\text { Did/Do you as an } \\
\text { online student have } \\
\text { another person do } \\
\text { your exam? }\end{array}$ & 3 & 1.8 & 4 & 2.5 & 64 & 39.3 & 45 & 27.6 & 47 & 28.8 \\
\hline $\begin{array}{l}\text { Did/Do you as an } \\
\text { online student obtain } \\
\text { the exam questions } \\
\text { from another student } \\
\text { who did the test } \\
\text { before you? }\end{array}$ & 8 & 4.9 & 13 & 8.0 & 39 & 23.9 & 64 & 39.3 & 39 & 23.9 \\
\hline $\begin{array}{l}\text { Did/Do you as an } \\
\text { online student help } \\
\text { other students during } \\
\text { the exam? }\end{array}$ & 10 & 6.1 & 9 & 5.5 & 54 & 33.1 & 55 & 33.7 & 35 & 21.5 \\
\hline $\begin{array}{l}\text { Did/Do you as an } \\
\text { online student send } \\
\text { the answers to other } \\
\text { students? }\end{array}$ & 12 & 7.4 & 10 & 6.1 & 47 & 28.8 & 55 & 33.7 & 39 & 23.9 \\
\hline $\begin{array}{l}\text { Did/Do you as an } \\
\text { online student } \\
\text { have the ID of other } \\
\text { students and answer } \\
\text { their exam? }\end{array}$ & 3 & 1.8 & 4 & 2.5 & 63 & 38.7 & 49 & 30.1 & 44 & 27.0 \\
\hline $\begin{array}{l}\text { Did/Do you as an } \\
\text { online student use } \\
\text { Google or other online } \\
\text { sources to copy and } \\
\text { paste the correct } \\
\text { answers? }\end{array}$ & 14 & 8.6 & 28 & 17.2 & 92 & 56.4 & 19 & 11.7 & 10 & 6.1 \\
\hline $\begin{array}{l}\text { Did/Do you as an } \\
\text { online student consult } \\
\text { with other people } \\
\text { during an online } \\
\text { exam? }\end{array}$ & 18 & 11.0 & 34 & 20.9 & 71 & 43.6 & 26 & 16.0 & 14 & 8.6 \\
\hline $\begin{array}{c}\text { Did/Do you as an } \\
\text { online student retain } \\
\text { or copy an exam for } \\
\text { future use? }\end{array}$ & 9 & 5.5 & 7 & 4.3 & 45 & 27.6 & 49 & 30.1 & 53 & 32.5 \\
\hline $\begin{array}{l}\text { Did/Do you as an } \\
\text { online student use } \\
\text { personal class notes } \\
\text { during an online } \\
\text { exam? }\end{array}$ & 20 & 12.3 & 50 & 30.7 & 51 & 31.3 & 27 & 16.6 & 15 & 9.2 \\
\hline
\end{tabular}


According to Table 3, the four top methods of cheating which are most frequently used by Turkish higher education learners are 'using Google or other online sources to copy and paste the correct answers' (82.2\%), 'consulting with other people during an online exam' (75.5\%), 'using personal class notes during an online exam' (74.3\%), and 'opening the coursebook during an online exam' (73.6\%). Similar findings were revealed by previous researchers such as Best and Shelley (2018) as well as Saleh and Meccawy (2021).

\section{Reasons for Cheating in Online Exams}

Table 4. Turkish Higher Education Learners' Perceptions about Reasons for Cheating

\begin{tabular}{|c|c|c|c|c|c|c|c|c|}
\hline & \multicolumn{2}{|c|}{$\begin{array}{l}\text { Strongly } \\
\text { Disagree }\end{array}$} & \multicolumn{2}{|c|}{ Disagree } & \multicolumn{2}{|c|}{ Agree } & \multicolumn{2}{|c|}{ Strongly Agree } \\
\hline & 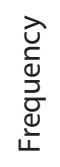 & 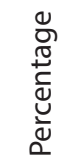 & 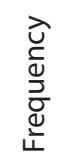 & 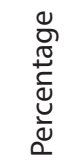 & 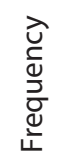 & 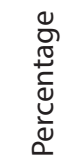 & 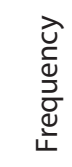 & 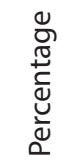 \\
\hline $\begin{array}{l}\text { I cheat(ed) because I only want(ed) grades, } \\
\text { not knowledge. }\end{array}$ & 58 & 35.6 & 55 & 33.7 & 18 & 11.0 & 32 & 19.6 \\
\hline $\begin{array}{l}\text { I cheat(ed) because of my frequent } \\
\text { absence from the virtual (online) } \\
\text { classrooms, and the misunderstanding of } \\
\text { the content. }\end{array}$ & 65 & 39.9 & 47 & 28.8 & 18 & 11.0 & 33 & 20.2 \\
\hline $\begin{array}{l}\text { I cheat(ed) because I do/did not learn } \\
\text { the content well in the virtual (online) } \\
\text { classrooms. }\end{array}$ & 59 & 36.2 & 50 & 30.7 & 24 & 14.7 & 30 & 18.4 \\
\hline $\begin{array}{l}\text { I cheat(ed) because of the short time of } \\
\text { online tests. }\end{array}$ & 57 & 35.0 & 48 & 29.4 & 9 & 5.5 & 49 & 30.1 \\
\hline $\begin{array}{l}\text { I cheat(ed) because other classmates are/ } \\
\text { were cheating. }\end{array}$ & 48 & 29.4 & 46 & 28.2 & 28 & 17.2 & 41 & 25.2 \\
\hline $\begin{array}{l}\text { I cheat(ed) because of some technical } \\
\text { problems. For example, I cannot get } \\
\text { connected on time, but I have to finish the } \\
\text { test on time. }\end{array}$ & 55 & 33.7 & 44 & 27.0 & 20 & 12.3 & 44 & 27.0 \\
\hline
\end{tabular}

Based on Table 4, few participants pointed to the reasons for cheating in the questionnaire. Less than half of the participants (42.4\%) stated that they cheated because other classmates were cheating. 39.3\% of the respondents said that they cheated because of some technical problems. For example, they were not able to get connected on time, but they had to finish the test on time. A little more than a third of them $(35.6 \%)$ said that they cheated because of the short time of online tests. About a third of them $(33.1 \%)$ stated that they cheated because they did not learn the content well in the virtual (online) classrooms.

Nevertheless, as for the reasons mentioned by the participants in their answers to the open-ended question, which asked them why they cheated in their online exams, 24 participants clearly stated that they cheated to get either passing score or higher marks. 14 respondents explained that cheating is easy, so they use this opportunity. 11 learners confessed that they had not studied and thus they did not have the knowledge to answer the exam questions. The other mentioned reasons were 'no proctor or no proctoring', 'exam stress', and 'exam difficulty'. The reasons for cheating mentioned by Turkish higher education online learners were found by previous researchers in other countries, too (Jones, 2011; Yang et al., 2013). What follows is the extract of some Turkish higher education online learners' responses. The letter $\mathrm{R}$ represents 'Respondent' and the number that follows represents the number of the participant who responded. 
R.7: $\quad$ "In case we have technical and internet or power-outage problems, it is really painful and bothersome because well be involved in a long bureaucracy; we have to request the university to permit us to compensate for our exam and university wants some evidence from us to show the reason of these problems and it is a problem and even sometimes they reject our compensation request and because of these stressful situations we can cheat and answer very fast and avoid having these problems."

R.22: "There is no control on students; they can cheat easily; we are not forced to turn on our laptop camera and also our online system has not that capacity and internet power to allow teachers or proctors to see all of us at the same time.

Because no one is checking. There is not a real face-to-face proctor to keep an eye on us and walk in the classroom to see what exactly we are doing."

R.41: "I believe if there is no control, everything is possible. Students have the tendency to cheat in even face-to-face exams and sometimes they really try hard for that. So, I think they will follow this tendency during online exam as expected."

R. 112: "Students have opportunity to get a good grade in the exams, therefore, they just use this opportunity. Other friends do that; I prefer to do it too to have good scores like them."

\section{Solutions to Minimize Cheating}

Table 5. Turkish Higher Education Learners' Solutions to Minimize Cheating

\begin{tabular}{|c|c|c|c|c|c|c|c|c|}
\hline & \multicolumn{2}{|c|}{$\begin{array}{l}\text { Strongly } \\
\text { Disagree }\end{array}$} & \multicolumn{2}{|c|}{ Disagree } & \multicolumn{2}{|c|}{ Agree } & \multicolumn{2}{|c|}{ Strongly Agree } \\
\hline & $\begin{array}{l}\text { ปे } \\
\frac{c}{d} \\
\frac{0}{0} \\
\frac{d}{4}\end{array}$ & 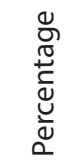 & $\begin{array}{l}\text { ত̀े } \\
\frac{c}{\Phi} \\
\frac{0}{0} \\
\frac{d}{4}\end{array}$ & 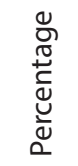 & $\begin{array}{l}\text { তे } \\
\frac{c}{\Phi} \\
\frac{0}{0} \\
\frac{d}{4}\end{array}$ & 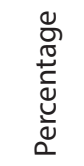 & $\begin{array}{l}\text { ปे } \\
\frac{c}{\omega} \\
\frac{0}{0} \\
\frac{d}{4}\end{array}$ & 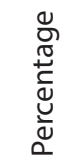 \\
\hline $\begin{array}{l}\text { To prevent cheating, teachers should } \\
\text { shorten the course syllabus. }\end{array}$ & 20 & 12.3 & 50 & 30.7 & 23 & 14.1 & 70 & 42.9 \\
\hline $\begin{array}{l}\text { In order to prevent cheating, teachers } \\
\text { should create different quizzes for each } \\
\text { student. }\end{array}$ & 41 & 25.2 & 39 & 23.9 & 22 & 13.5 & 61 & 37.4 \\
\hline $\begin{array}{l}\text { To prevent cheating, teachers should } \\
\text { make sure that all students access the test } \\
\text { at the same time. }\end{array}$ & 20 & 12.3 & 30 & 18.4 & 22 & 13.5 & 91 & 55.8 \\
\hline $\begin{array}{l}\text { In order to prevent cheating, teachers } \\
\text { should require all students to start their } \\
\text { webcam during the online test so that } \\
\text { teachers can proctor them. }\end{array}$ & 49 & 30.1 & 45 & 27.6 & 20 & 12.3 & 49 & 30.1 \\
\hline $\begin{array}{l}\text { To prevent cheating, the university should } \\
\text { disable the copy and paste features from } \\
\text { all platforms during exams. }\end{array}$ & 20 & 12.3 & 45 & 27.6 & 32 & 19.6 & 66 & 40.5 \\
\hline
\end{tabular}

As Table 5 shows, to prevent cheating, $69.3 \%$ of the respondents stated that teachers should make sure that all students access the test at the same time. $60.1 \%$ of them mentioned that universities should disable the copy and paste features from all platforms during exams. $57.0 \%$ of the participants believed that teachers should shorten the course syllabus to prevent cheating. Half of the students (50.9\%) said that teachers should create different quizzes for each student. Less than half of the learners $(42.4 \%)$ stated that to prevent cheating, teachers should require all students to start their webcam during the online test so that teachers can proctor them. 
Considering the respondents' answers to the open-ended which required them to suggest their possible solutions to prevent cheating, 11 students clearly stated that nothing can be done either due to some technical infrastructure problems such as low-speed internet or the non-existence of online procuring system and even because of some lazy teachers. The following are some of the respondents' answers. The letter $\mathrm{R}$ represents 'Respondent' and the number that follows represents the number of the participant who responded.

R.34: "I don't think that cheating can be prevented no matter what is done as long as there is online education. The face to face education should be started."

R.56: "I say sadly there is no solution to prevent cheating. Some teachers also want to be relaxed and they themselves are lazy at controlling us despite the fact that university has ordered them to control us; they do not control us."

R.79: "In my opinion, there is no way to prevent cheating in online learning. Teachers should not be lazy and irresponsible and should do their duties and do not let students do whatever they want during the exam."

R.83: "Because the seriousness of the real classroom environment is not felt. There is not a real face-to-face proctor to keep an eye on us and walk in the classroom to see what exactly we are doing; teachers are also lazy and not careful with online education control; they want to use this opportunity to be relaxed too."

R.128: "Our online system has not that capacity and internet power to allow teachers or proctors to see all of us at the same time; most online systems can have 3-4 cameras opened at the same time and there are many students and teacher cannot check our cameras before the exam because it is timeconsuming and hard. They cannot control us during the exam, either."

R.131: "Our system has not that capacity (internet signal power) and ability to monitor all of us by our cameras during the exam at the same time. In our university, they want us to turn on our cameras one by one only before the exam to see who we are, but during the exam, we can easily cheat."

R.157: "We can keep the camera open during the exam, but some online platforms in remote education have not this capacity or internet signal is weak and proctors cannot see all the students at the same time."

Previous research revealed that proctoring is crucial in reducing cheating (Dyer, Pettyjohn, \& Saladin, 2020; Harmon et al., 2010). Several studies already suggested that using technology is essential for reducing the opportunity of cheating in online exams, for instance, a device, called 'Secure Software Remote Proctor', including a fingerprint scanner and a 360-degree camera, can be utilized to prevent online cheating (Bedford, Gregg, \& Clinton, 2009, 2011). Likewise, some software that contain an e-proctoring scheme and authentication, can detect and prevent cheating by providing a secure online exam management environment (Dendir \& Maxwell, 2020; Jung \& Yeom, 2009). It has also been suggested that teachers use webcam-based proctoring to prevent online cheating (Hylton, Levy, \& Dringus, 2016). Despite the mentioned points, there are several challenges and limitations to utilizing online proctoring technological devices (Golden \& Kohlbeck, 2020). The first challenge is regarding both time and money for not only the university but also students. Some universities and some students cannot afford them (Cluskey Jr, Ehlen, \& Raiborn, 2011), which is apparently a problem in Turkey, as explained by the participating students in the present study. Nonetheless, four of the Turkish higher education participating learners in the current study, as well as some newspapers in Turkey, reported that Bilkent University in Ankara sent all its students medium-sized mirrors to put behind them while taking tests to ensure there is nothing on their screens or behind them that can help them. As Chancellor Abdullah Atalar told the reporters the students even did not touch the keyboard or the mouse; the teachers saw their hands. The students wrote their answers in their own handwriting and then scanned their answers and sent them to university, so they could be graded by their instructors (Alemdar, 2020; Papadopoulos, 2020). Atalar told the TRT World that the cost for the 11,500 mirrors produced was not that high: "About \$3-4 per household." (Alemdar, 2020). Consequently, the same action can be done in several distance education universities in Turkey. 
In addition, ten participants recommended alternative methods of assessment and formative assessment instead of the formal summative one. The following are some of the participants' answers. The letter $\mathrm{R}$ represents 'Respondent' and the number that follows represents the number of the participant who responded.

R.3: $\quad$ "Homework should be given instead of exams. Instead of these exams, special assignments can be given and then be used in the evaluation process. In this case, the teacher has a lot of work, but if the goal is to teach and prevent cheating, this can be done."

R.11: "I think it would be better to give the exams in the form of homework instead of formal tests because it is understood how much the student knows about the subject by the answers given in the homework and the situation of cheating is reduced in this way."

R.142: "This situation can be prevented by replacing the exam with homework or projects. Personally, I prefer homework instead of some online exams because I believe doing research on something is more important in learning."

R.149 "During the classes, there should be small quizzes. Only 1 or 2 exams are not enough to assess the students' learning. Maybe projects also do the job."

This solution can be effective because it has already been shown that teaching approaches which does not measure learning only by grades, getting higher grades is not the only incentive for studying, so the occurrence of cheating is diminished (Day, Hudson, \& Dobies, 2011; Pulfrey, Vansteenkiste, \& Michou, 2019).

Eight students suggested preparing open-ended or essay like questions which entail personal analyses or are thought-provoking. The following are some of the respondents' answers.

R.56: "It all depends on the quality of the questions in the exam. I was glad to see some improvements here. Our teachers started to put more effort into formulating thought-provoking questions. In my humble opinion, a good teacher who prepares well-planned questions does not have any worries about cheating."

R.118: "There should be essay-type questions by which the students can truly show their skills. Moreover, questions should not seek for students' memorization; when questions can be answered only based on memorization, we can find them easily on the Google; they should be analytical or be answered by integration of information."

R.160: "The questions should be aimed at evaluating learning. Instead of asking detailed questions to measure students' memorization, teachers should assess students' information. For example, Teachers can prepare exams that need students to express their own opinion and write them like an essay."

As for this point, the grading of essay-type questions is time-consuming and sometimes impossible in online programs, which can be a huge disadvantage. On the other hand, multiple-choice questions are efficient, objective, easy to grade automatically, and thus are utilized in online exams (Towns, 2014; Zaidi et al., 2018). Although most of the multiple-choice questions are only knowledge level ones, they can be created in a way that promote critical thinking (Nguyen et al., 2020; Zaidi et al., 2018). Additionally, to save time, test bank questions consisting of multiple-choice questions, are usually utilized (Burns, 2009). However, because learners in online exams can use the Internet to search for answers to specific questions, paraphrasing the test bank questions will significantly reduce the chance of gaining benefits from cheating in online exams (Golden \& Kohlbeck, 2020).

Three students recommended some forms of creating awareness of the problem. For example, one of them said:

R.19: "Students should be informed and be explained that the information/knowledge learned will affect their lives; without this information/knowledge, the diploma will be a useless paper; teachers need to instill this idea in the students by talking to them or having mini-ethic lessons or courses. The country certainly needs this generation's knowledge in the future." 
As Michaeland Williams (2013) maintained, it is critical that faculty and administrators create awareness of the problem of cheating. Students need to understand there is value in academic integrity. When students understand why they are prevented from cheating, they will be more committed to academic integrity. They will also take pride in their work (Michael \& Williams, 2013). In this regard, research already documented the crucial role of honor code systems, as well as faculty and institutional efforts to increase students' awareness of academic integrity rules and decreasing the incidences of cheating (R. Arnold, Martin, \& Bigby, 2007; Burrus, McGoldrick, \& Schuhmann, 2007; McCabe, Trevino, \& Butterfield, 2002; Tatum \& Schwartz, 2017).

In Bilkent University in Turkey, there is also the 'honor pledge'. The 'honor pledge' of Bilkent University says:

"I pledge on my honour that the work that I will submit for my final exams will be entirely my own. I will not receive or utilize any unauthorized assistance from any source, nor will I provide such assistance to others. I understand and accept that any violation of integrity on my part will result in a disciplinary hearing and may lead to severe penalties"(Alemdar, 2020).

\section{CONCLUSION}

This study highlighted the Turkish higher education learners' perceptions of cheating on online learning programs, the ways of, causes for, and some suggestions to minimize cheating. Over half of the respondents believed that cheating is more frequent and easier in an online course and they take this opportunity. They cheated by 'using online sources, like Google to copy and paste the answers', 'consulting with others, and 'using personal class notes or coursebook'. They cheated because of 'lack of knowledge', 'getting higher marks', 'some technical problems', 'no proctoring', and 'exam stress'. To prevent cheating the respondents suggested that universities should disable the copy and paste features. Teachers should create different quizzes for each student, require all students to start their webcam during the online test, use alternative methods of assessment, prepare essay like thought-provoking questions, and create awareness of the problem. However, some students clearly stated that nothing can be done either due to some technical infrastructure problems or even lazy teachers.

As online education is expanding worldwide in all types of higher education institutions, faculty and administrators continue to deal with a variety of issues related to the online education, including both quality of instruction and learning, as well as quality of assessment (Dendir \& Maxwell, 2020). Although empirical evidence indicated cheating is more common in online education, the debate is not resolved yet (Harton, Aladia, \& Gordon, 2019; Peled et al., 2019). Consequently, this study aimed at increasing information on this issue, especially in Turkey because as Chancellor Atalar told the TRT World, we need to take precautions to prevent cheating for the students' own good. Chancellor Abdullah Atalar maintained that all universities in Turkey, like Bilkent University,

"care about the reputation of its students. We do not want our students who graduate during the pandemic to have a lesser valued diploma just because people are suspicious whether they received their grades by cheating or studying. We are doing this to say 'You can trust our graduates' grades" (Alemdar, 2020).

Nevertheless, cheating is a sensitive issue and participants of the current study may not be honest in their responses and their actual behaviour may differ from what they expressed. (Hard, Conway, \& Moran, 2006; Howard, 2019), which is a limitation in this study. Moreover, the current study was small-scale, including 163 higher education learners' perceptions in Turkey, which can affect generalizability of the findings.

As the concluding remarks, it is suggested that future studies on cheating on distance learning platforms in Turkey compare students' cheating across various online courses at various universities to discover the most vulnerable courses susceptible to cheating in addition to the students' reasons behind their acts of cheating. 


\section{BIODATA and CONTACT ADDRESSES of AUTHOR}

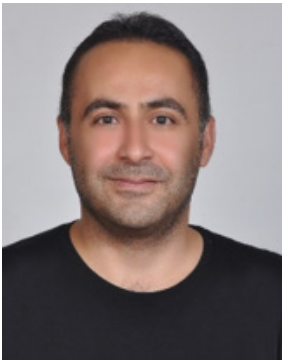

Mohammadreza VALIZADEH holds a PhD in TEFL from Gazi University, Ankara, Turkey and is currently an assistant professor at Cappadocia University, Cappadocia, Turkey. He has published several articles in different scholarly journals. His areas of interests include corrective feedback, CALL, psycholinguistics, learning strategies, learner autonomy, task-based language teaching and individual differences in language learning.

\section{Mohammadreza VALIZADEH}

Department of Translation and Interpretation (English), Faculty of Humanities

Address: Cappadocia University, 50420, Urgup, Nevsehir, Turkey

Phone: +90 5346568587

E-mail: mrvalizadeh2015@gmail.com

\section{REFERENCES}

Alemdar, M. (2020, December 25). A Turkish university sends every student a mirror to cheat-proof exams. TRT World. Retrieved from https://www.trtworld.com/life/a-turkish-university-sends-everystudent-a-mirror-to-cheat-proof-exams- 42684

Appana, S. (2008). A review of benefits and limitations of online learning in the context of the student, the instructor, and the tenured faculty. International Journal on E-Learning, 7(1), 5-22. Retrieved from https://www.researchgate.net/publication/237143888_A_Review_of_Benefits_and_ Limitations_of_Online_Learning_in_the_Context_of_the_Student_the_Instructor_and_the_ Tenured_Faculty/link/5c0741efa6fdcc315f9de15a/download

Arnold, I. J. M. (2016). Cheating at online formative tests: Does it pay off? The Internet and Higher Education, 29, 98-106. https://doi.org/10.1016/j.iheduc.2016.02.001

Arnold, R., Martin, B. N., \& Bigby, L. (2007). Is there a relationship between honor codes and academic dishonesty? Journal of College and Character, 8(2), 1-20. https://doi.org/10.2202/19401639.1164

Bedford, D. W., Gregg, J., \& Clinton, S. (2009). Implementing technology to prevent online cheating: A case study at a small southern regional university (SSRU). MERLOT Journal of Online Learning and Teaching, 5(2), 230-238. Retrieved from https://jolt.merlot.org/vol5no2/ gregg_0609.pdf

Bedford, D. W., Gregg, J. R., \& Clinton, M. S. (2011). Preventing online cheating with technology: A pilot study of remote proctor and an update of its use. Journal of Higher Education Theory and Practice, 11(2), 41-58. Retrieved from http://m.www.na-businesspress.com/JHETP/BedfordWeb.pdf

Best, L. M., \& Shelley, D. J. (2018). Academic dishonesty: Does social media allow for increased and more sophisticated levels of student cheating? International Journal of Information and Communication Technology Education, 14(3), 1-13. https://doi.org/10.4018/IJICTE.2018070101

Black, E. W., Greaser, J., \& Dawson, K. (2019). Academic dishonesty in traditional and online classrooms: Does the "media equation" hold true? Online Learning, 12(3-4), 23-30. https://doi.org/10.24059/ olj.v12i3-4.1681

Braun, V., \& Clarke, V. (2006). Using thematic analysis in psychology. Qualitative Research in Psychology, 3(2), 77-101. https://doi.org/10.1191/1478088706qp063oa

Burns, C. M. (2009). Sold! Web-based auction sites have just compromised your test bank. Nurse Educator, 34(3), 95-96. https://doi.org/10.1097/NNE.0b013e3181a18c25 
Burrus, R. T., McGoldrick, K., \& Schuhmann, P. W. (2007). Self-reports of student cheating: Does a definition of cheating matter? The Journal of Economic Education, 38(1), 3-16. https://doi. org/10.3200/JECE.38.1.3-17

Cluskey Jr, G. R., Ehlen, C. R., \& Raiborn, M. H. (2011). Thwarting online exam cheating without proctor supervision. Journal of Academic and Business Ethics, 4, 1-7. Retrieved from https://www.aabri. com/manuscripts/11775.pdf

Corrigan-gibbs, H., Gupta, N., Northcutt, C., Cutrell, E., \& Thies, W. (2015). Deterring cheating in online environments. ACM Transactions on Computer-Human Interaction, 22(6), 1-23. https:// doi.org/10.1145/2810239

Day, N. E., Hudson, D., \& Dobies, P. R. (2011). Student or situation? Personality and classroom context as predictors of attitudes about business school cheating. Social Psychology of Education, 14(2), 261-282. https://doi.org/10.1007/s11218-010-9145-8

Dendir, S., \& Maxwell, R. S. (2020). Cheating in online courses: Evidence from online proctoring. Computers in Human Behavior Reports, 2, 1-10. https://doi.org/10.1016/j.chbr.2020.100033

Diego, L. A. B. . (2017). Friends with benefits: Causes and effects of learners' cheating practices during examination. IAFOR Journal of Education, 5(2), 121-138. https://doi.org/10.22492/ije.5.2.06

Dumford, A. D., \& Miller, A. L. (2018). Online learning in higher education: Exploring advantages and disadvantages for engagement. Journal of Computing in Higher Education, 30(3), 452-465. https:// doi.org/10.1007/s12528-018-9179-z

Dyer, J., Pettyjohn, H., \& Saladin, S. (2020). Academic dishonesty and testing: How student beliefs and test settings impact decisions to cheat. Journal of the National College Testing Association, 4(1), 1-30. Retrieved from https://www.researchgate.net/publication/341296878_Academic_Dishonesty_ and_Testing_How_Student_Beliefs_and_Test_Settings_Impact_Decisions_to_Cheat

Erkut, E. (2020). Covid-19 Sonrasi Yuksekogretim [Higher education after Covid-19]. Yuksekogretim Dergisi - Journal of Higher Education (Turkey), 10(2), 125-133. https://doi.org/10.2399/yod.20.002

Finchilescu, G., \& Cooper, A. (2018). Perceptions of academic dishonesty in a South African university: A q-methodology approach. Ethics \& Behavior, 28(4), 284-301. https://doi.org/10.1080/1050842 2.2017 .1279972

Golden, J., \& Kohlbeck, M. (2020). Addressing cheating when using test bank questions in online classes. Journal of Accounting Education. https://doi.org/10.1016/j.jaccedu.2020.100671

Gunes, A. (2020, May 9). Pandemic could be an opportunity for Turkish higher education. University World News: The Global Window on Higher Education. Retrieved from https://www.universityworldnews. com/post.php?story $=20200506061559172$

Hard, S. F., Conway, J., \& Moran, A. C. (2006). Faculty and college student beliefs about the frequency of student academic misconduct. The Journal of Higher Education, 77(6), 1058-1080. https://doi. org $/ 10.1353 /$ jhe. 2006.0048

Harmon, O. R., Lambrinos, J., \& Buffolino, J. (2010). Assessment design and cheating risk in online instruction. Online Journal of Distance Learning Administration, 13(3). Retrieved from https:// www2.westga.edu/ distance/ojdla/Fall133/harmon_lambrinos_buffolino133.html

Harton, H. C., Aladia, S., \& Gordon, A. (2019). Faculty and student perceptions of cheating in online vs. traditional classes. Online Journal of Distance Learning Administration, 22(4). Retrieved from https://www.westga.edu/ - distance/ojdla/winter224/hartonaladiagordon224.html

Hearn Moore, P., Head, J. D., \& Griffin, R. B. (2017). Impeding students' efforts to cheat in online classes. Education, Journal of Learning in Higher, 13(1), 9-23. Retrieved from https://files.eric.ed.gov/ fulltext/EJ1139692.pdf

Hodges, C., Moore, S., Lockee, B., Trust, T., \& Bond, A. (2020). The difference between emergency remote teaching and online learning. EDUCAUSE Review. Retrieved from https://er.educause.edu/ articles/2020/3/the-difference-between-emergency-remote-teaching-and- online-learning 
Hosny, M., \& Fatima, S. (2014). Attitude of students towards cheating and plagiarism: University case study. Journal of Applied Sciences, 14(8), 748-757. https://doi.org/10.3923/jas.2014.748.757

Howard, D. (2019). Online testing integrity in a general education math course: A correlational study. (Doctoral dissertation). American College of Education. Retrieved from https://search.proquest. com/openview/b0235bd6a6ffa3d3864cdd00a8848d3c/1?pq-origsite=gscholar\&cbl=2026366\&d iss $=\mathrm{y}$

Hylton, K., Levy, Y., \& Dringus, L. P. (2016). Utilizing webcam-based proctoring to deter misconduct in online exams. Computers \& Education, 92-93, 53-63. https://doi.org/10.1016/j.compedu.2015.10.002

Jian, H., Li, G., \& Wang, W. (2020). Perceptions, contexts, attitudes, and academic dishonesty in Chinese senior college students: A qualitative content-based analysis. Ethics \& Behavior, 30(7), 543-555. https://doi.org/10.1080/10508422.2020.1711758

Jones, D. L. R. (2011). Academic dishonesty: Are more students cheating? Business Communication Quarterly, 74(2), 141-150. https://doi.org/10.1177/1080569911404059

Jung, I. Y., \& Yeom, H. Y. (2009). Enhanced security for online exams using group cryptography. IEEE Transactions on Education, 52(3), 340-349. https://doi.org/10.1109/TE.2008.928909

Kamal, A., \& Radhakrishnan, S. (2019). Individual learning preferences based on personality traits in an E-learning scenario. Education and Information Technologies, 24(1), 407-435. https://doi. org/10.1007/s10639-018-9777-4

Kaya, M. (2012). Social and distance education systems used in universities of Turkey and Northern Cyprus. Procedia - Social and Behavioral Sciences, 31, 676-680. https://doi.org/10.1016/j. sbspro.2011.12.123

Kim, K., Liu, S., \& Bonk, C. J. (2005). Online MBA students' perceptions of online learning: Benefits, challenges, and suggestions. Internet and Higher Education, 8, 335-344. https://doi.org/10.1016/j. iheduc.2005.09.005

King, C. G., Guyette, R. W., \& Piotrowski, C. (2009). Online exams and cheating: An empirical analysis of business students' views. The Journal of Educators Online, 6(1), 1-11. https://doi.org/10.9743/ JEO.2009.1.5

McCabe, D. L., Trevino, L. K., \& Butterfield, K. D. (2002). Honor codes and other contextual influences on academic integrity: A replication and extension to modified honor code settings. Research in Higher Education, 43, 357-378. https://doi.org/10.1023/A:1014893102151

McGee, P. (2013). Supporting academic honesty in online courses. Journal of Educators Online, 10(1). Retrieved from https://files.eric.ed.gov/fulltext/EJ1004890.pdf

Michael, T. B., \& Williams, M. A. (2013). Student equity: Discouraging cheating in online courses. Administrative Issues Journal, 3(2). https://doi.org/10.5929/2013.3.2.8

Miller, A., \& Young-Jones, A. D. (2012). Academic integrity: Online classes compared to face-toface classes. Ournal of Instructional Psychology, 39, 138-145. Retrieved from https://www. researchgate.net/publication/260969851_Academic_integrity_Online_classes_compared_to_ face-to-face_classes

Nassaji, H. (2020). Good qualitative research. Language Teaching Research, 24(4), 427-431. https://doi. org/10.1177/1362168820941288

Nguyen, J. G., Keuseman, K. J., \& Humston, J. J. (2020). Minimize online cheating for online assessments during COVID-19 pandemic. Journal of Chemical Education. https://doi.org/10.1021/acs. jchemed.0c00790

Pallant, J. (2013). SPSS survival manual: A step by step guide to data analysis using IBM SPSS (5th. ed.). Berkshire, England: Open University Press.

Papadopoulos, L. (2020, December 26). Turkish university mails over 10,000 mirrors to prevent students from cheating. INTERESTING ENGINEERING. Retrieved from https://interestingengineering. $\mathrm{com} /$ turkish-university-mails-over-10000-mirrors-to-prevent-students-from-cheating 
Park, J.-H., \& Choi, H. J. (2009). Factors influencing adult learners' decision to drop out or persist in online learning. Educational Technology \& Society, 12(4), 207-217. Retrieved from https://www.jstor.org/ stable/pdf/jeductechsoci.12.4.207.pdf?_=1459005475270

Patton, M. Q. (2014). Qualitative research and evaluation methods: Integrating theory and practice (4th. ed.). Thousand Oaks, CA: SAGE Publications, Inc.

Peled, Y., Eshet, Y., Barczyk, C., \& Grinautski, K. (2019). Predictors of academic dishonesty among undergraduate students in online and face-to-face courses. Computers \& Education, 131, 49-59. https://doi.org/10.1016/j.compedu.2018.05.012

Pulfrey, C. J., Vansteenkiste, M., \& Michou, A. (2019). Under pressure to achieve? The impact of type and style of task instructions on student cheating. Frontiers in Psychology, 10, 1-18. https://doi. org/10.3389/fpsyg.2019.01624

Raines, D. A., Ricci, P., Brown, S. L., Eggenberger, T., Hindle, T., \& Schiff, M. (2011). Cheating in online courses: The student definition. The Journal of Effective Teaching, 11(1), 80-89. Retrieved from https://files.eric.ed.gov/fulltext/EJ1092169.pdf

Razek, N. (2014). Academic integrity: A Saudi student perspective. Academy of Educational Leadership Journal, 18(1), 143-154. Retrieved from https://ecommons.udayton.edu/cgi/viewcontent. cgi?article=1002\&context=edc_fac_pub

Reichertz, J. (2014). Induction, deduction, abduction. In U. Flick (Ed.), The SAGE handbook of qualitative data analysis (pp. 123-135). London: SAGE Publications Ltd.

Saleh, A. M., \& Meccawy, Z. (2021). EFL female students' perceptions towards cheating in distance learning programmes. English Language Teaching, 14(1), 29-36. https://doi.org/10.5539/elt.v14n1p29

Sendag, S., Duran, M., \& Fraser, M. R. (2012). Surveying the extent of involvement in online academic dishonesty (e-dishonesty) related practices among university students and the rationale students provide: One university's experience. Computers in Human Behavior, 28(3), 849-860. https://doi. org/10.1016/j.chb.2011.12.004

Srikanth, M., \& Asmatulu, R. (2014). Modern cheating techniques, their adverse effects on engineering education and preventions. International Journal of Mechanical Engineering Education, 42(2), 129 140. https://doi.org/10.7227/IJMEE.0005

Tashakkori, A., \& Teddlie, C. (Eds.). (2003). Handbook of mixed methods in social and behavioral research. Thousand Oaks, CA: Sage.

Tatum, H., \& Schwartz, B. M. (2017). Honor codes: Evidence based strategies for improving academic integrity. Theory Into Practice, 56(2), 129-135. https://doi.org/10.1080/00405841.2017.1308 175

Tekinarslan, E. (2008). Attitudes of Turkish distance learners toward Internet-based learning: An investigation depending on demographical characteristics. Turkish Online Journal of Distance Education-TOJDE, 9(1), 67-84. Retrieved from https://files.eric.ed.gov/fulltext/ED499478.pdf

Towns, M. H. (2014). Guide to developing high-quality, reliable, and valid multiple-choice assessments. Journal of Chemical Education, 91(9), 1426-1431. https://doi.org/10.1021/ed500076x

Watson, G. R., \& Sottile, J. (2010). Cheating in the digital age: Do students cheat more in online courses? Online Journal of Distance Learning Administration, 13(1). Retrieved from https://mds.marshall. edu/cgi/viewcontent.cgi?article=1000\&context=eft_faculty

Yang, S. C., Huang, C., \& Chen, A. (2013). An investigation of college students' perceptions of academic dishonesty, reasons for dishonesty, achievement goals, and willingness to report Dishonest Behavior. Ethics \& Behavior, 23(6), 501-522. https://doi.org/10.1080/10508422.2013.802651

Zaidi, N. L. B., Grob, K. L., Monrad, S. M., Kurtz, J. B., Tai, A., Ahmed, A. Z., ... Santen, S. A. (2018). Pushing critical thinking skills with multiple-choice questions. Academic Medicine, 93(6), 856-859. https://doi.org/10.1097/ACM.0000000000002087 